
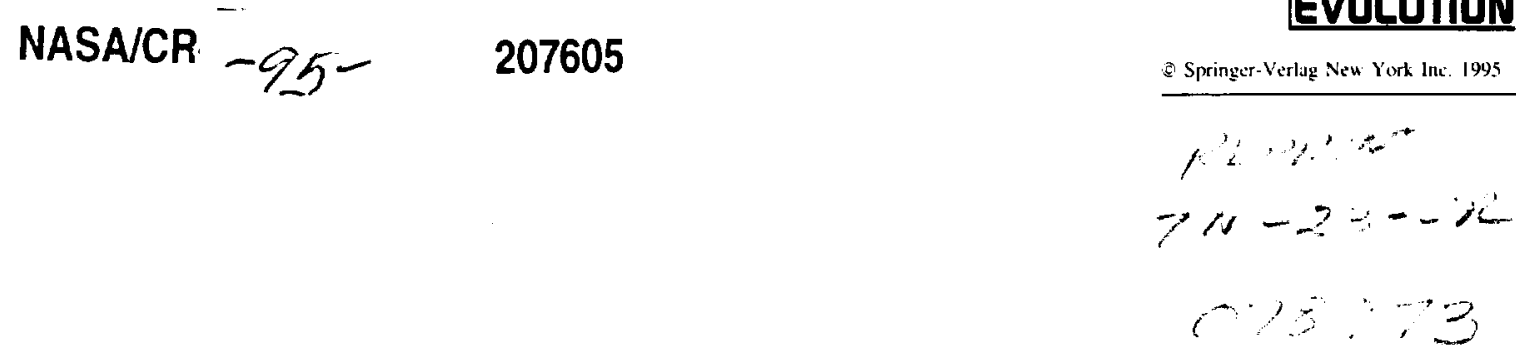

\title{
Are Polyphosphates or Phosphate Esters Prebiotic Reagents?
}

\author{
Anthony D. Keefe,* Stanley L. Miller \\ Department of Chemistry and Biochemistry. University of California, San Diego. La Jolla. CA 92093-0317. USA \\ Received: 2 June 1995 / Accepted: 25 July 1995
}

\begin{abstract}
It is widely held that there was a phosphate compound in prebiotic chemistry that played the role of adenosine triphosphate and that the first living organisms had ribose-phosphate in the backbone of their genetic material. However, there are no known efficient prebiotic synthesis of high-energy phosphates or phosphate esters. We review the occurrence of phosphates in $\mathrm{Na}$ ture, the efficiency of the volcanic synthesis of $\mathrm{P}_{4} \mathrm{O}_{10}$, the efficiency of polyphosphate synthesis by heating phosphate minerals under geological conditions, and the use of high-energy organic compounds such as cyanamide or hydrogen cyanide. These are shown to be inefficient processes especially when the hydrolysis of the polyphosphates is taken into account. For example, if a whole atmosphere of methane or carbon monoxide were converted to cyanide which somehow synthesized polyphosphates quantitatively, the polyphosphate concentration in the ocean would still have been insignificant. We also attempted to find more efficient high-energy polymerizing agents by spark discharge syntheses, but without success. There may still be undiscovered robust prebiotic syntheses of polyphosphates, or mechanisms for concentrating them, but we conclude that phosphate esters may not have been constituents of the first genetic material. Phosphoanhydrides are also unlikely as prebiotic energy sources.
\end{abstract}

Key words: Orthophosphate - Polyphosphates Phosphorus pentoxide - Phosphate minerals - Highenergy organic compounds - Thermal condensation

*Present address: NASA Ames Research Center, M/S 239-4, Moffett Field, CA 94035

Correspondence io: S.L. Miller

\section{Introduction}

Adenosine triphosphate (ATP) is used to drive biochemical reactions, and it is widely held that there was a prebiotic phosphate compound capable of similar functions. This is an attractive idea since it is easy to envision the evolution of biochemical pathways from being polyphosphate driven to being ATP driven. However, there is no known robust synthesis of polyphosphates or even pyrophosphate, thereby raising the question of whether polyphosphates were used in prebiotic reactions and indeed if the pre-RNA world had informational macromolecules that contained phosphate at all. Here we discuss previously reported prebiotic polyphosphate syntheses, some experiments of our own, and then the possible future directions of research in this area. There have been a number of reviews of prebiotic phosphorylations (Lohrmann and Orgel 1973; Miller and Orgel 1974; Hulshof and Ponnamperuma 1976) but there have been no reviews since then, and recent developments suggest that this topic deserves reconsideration.

It is important to distinguish between phosphate in the prebiotic world, the pre-RNA world, the RNA world, and the DNA/protein world. It is clear that phosphate was involved in the RNA world and the DNA/protein world if the RNA world is taken to mean that the genetic material had a ribose-phosphate backbone (and a deoxyribose-phosphate backbone in the DNA/protein world). The free energy carrier may have been ATP or polyphosphates (Kornberg 1995) or pyrophosphate (Baltscheffsky 1993). It is not clear what was involved in the pre-RNA world: The backbone may not have contained phosphate and the free energy source may not have contained phosphate. The same choices apply to the prebiotic world. We intend to show that phosphate is an unlikely reagent for 
the prebiotic world, and this may also apply to the preRNA world. But our comments do not apply to the RNA world and the DNA/protein world.

\section{The Biological Occurrence of Phosphates}

The phosphate group is central to modern biological systems. It most widely occurs as phosphate diesters in the genetic materials RNA and DNA, as phosphoanhydrides in the cellular energy currency ATP, and as phosphomonoesters in numerous metabolic intermediates. The properties of phosphate that enable it to fulfill these many functions have often been remarked upon (Westheimer 1987; Kornberg 1995). These authors have pointed out that phosphate is trivalent and trianionic and therefore able to form a link in a chain and still retain negative charge. They also point out that the phosphoanhydride bond is a high-energy bond, and yet the residual negative charge means that it is relatively stable in water. Molecules bearing phosphate groups are not soluble in lipid phases and can be retained in cells; the phosphate group is also able to act as a buffer and a chelator of metal ions.

Although the arguments for the fitness of phosphate in contemporary biological systems are rather convincing, even if they are constructed after the fact, this only shows that biological systems have evolved to use an ideal system. There is no guarantee that the first biological organisms used such a perfected system. We cannot simply extrapolate backward from modern organisms, as this makes no allowance for evolution, and even more important, prebiotic chemistry may not be able to activate phosphate except in very unusual environments. It could be said that amino acids, purines, pyrimidines, and, to a lesser extent, sugars fall out of prebiotic synthesis experiments in a robust manner, and therefore it seems likely that the metabolic pathways of the first organisms were similar to the modern ones and that activated phosphate groups were also widely utilized. It would be convenient if this were the case, but we shall show that it may not be possible.

The principal reason that phosphate has been invoked in prebiotic scenarios is because of the back extrapolation of modern metabolic pathways, an exercise for which there is no support as most modern metabolic pathways have no prebiotic counterpart at all. All of the proposed reasons for the presence of phosphate could equally well be applied to various organic functional groups. Amide bonds are relatively stable in water; carboxylate groups carry negative charge and also have chelating and buffering potential. Many unsaturated compounds, such as cyanide, contain potentially utilizable free energy. It should also be pointed out that condensed phosphates do not act as external sources of energy for modern organisms. Some bacteria have been shown to grow more rapidly in the presence of pyrophosphate (Wood 1985), and some others use photophosphorylation to produce pyrophosphate rather than ATP (Baltscheffsky 1993). But in neither case has it been shown that the bacteria can use pyrophosphate as a source of energy.

Living organisms need a large amount of ATP to carry out biochemical processes. For example, humans produce approximately their own body weight of ATP per day. If the earliest organisms were to use ATP or a similar polyphosphate acquired from the environment as a source of energy, rather than as an internally produced mobile energy carrier, then they would have to assimilate similarly large amounts. Even if such large amounts were available in the environment, it is not clear whether this would be possible.

\section{The Geological Absence of Polyphosphates}

Except in living organisms and their products, polyphosphates are exceedingly rare on the modern Earth. No polyphosphate minerals have ever been discovered (Palache et al. 1951; Nriagu and Moore 1984) and there is only one known occurrence of a pyrophosphate mineral. This is a calcium pyrophosphate mineral of a few kilograms mass found in New Jersey (Rouse et al. 1988). However, there are low concentrations of dissolved polyphosphates (up to the tetramer) of volcanic origin that have been found in fumaroles by Yamagata et al. (1991). This source will be discussed below.

If it is to be claimed that polyphosphates were abundant on the early Earth, it is necessary to explain how the early Earth was different, and how such a difference could have resulted in the synthesis of polyphosphates. One difference of course was the absence of life. If present organisms were to use geologically produced polyphosphates, then this could account for their absence. There have been reports of bacteria which grow more rapidly in the presence of pyrophosphate (Wood 1985), but this does not appear to be a widespread phenomenon. In addition, organisms are likely to be a source of polyphosphates, at least in local areas, rather than a sink.

Another difference between the primitive Earth and the modern Earth is the presumed presence of highenergy organic compounds such as cyanoacetylene, cyanogen, and hydrogen cyanide. These compounds have high free energies of hydrolysis which could in theory be utilized in polymerization processes. These will also be discussed below.

Still another possible difference is the $\mathrm{pH}$ of the ocean or the type of phosphate mineral generally available. The $\mathrm{pH}$ of the ocean might have been different, but an explanation of how this could have happened is needed. A different phosphate mineral would also need an explanation. Hydroxy apatite, fluoro apatite, and other apatites are the predominant phosphate minerals on the Earth at present, with much, but not all, of it being precipitated by organisms. If apatite does not precipitate from sterile 
solutions, then the situation might have been different. But so far no convincing case for this has been made.

High concentrations of magnesium ions inhibit the precipitation of apatite and it has been proposed that struvite $\left(\mathrm{MgNH}_{4} \mathrm{PO}_{4} \cdot 4 \mathrm{H}_{2} \mathrm{O}\right)$ would have been the first phosphate mineral to have precipitated, rather than apatite (Martens and Harriss 1970; Handschuh and Orgel 1973). It is not clear whether the precipitation of apatite is slow enough on the geological time scale, in contrast to the laboratory time scale, so that sufficiently high concentrations could have accumulated. Another possibility is that the very insoluble ferric phosphate precipitated out, and was then reduced to the relatively soluble ferrous phosphate. This is a promising possibility since ferric is reduced to ferrous in the presence of organic matter and with ultraviolet light. This has not been reported as a phosphate concentration mechanism on the Earth today, but it may have been important in the past.

An important finding was made by Yamagata et al. (1991), who showed that acidic basalts containing apatite evolve phosphorus pentoxide $\left(\mathrm{P}_{4} \mathrm{O}_{10}\right)$ when heated to $1,200^{\circ} \mathrm{C}$. In addition they found approximately $5 \mu \mathrm{M}$ concentrations of pyrophosphate and tripolyphosphate in a fumarole near Mt. Usu in Hokkaido, Japan. This is by far the most convincing case for a prebiotic source of polyphosphates.

The synthesis in basalts can be written

$$
4 \mathrm{H}_{3} \mathrm{PO}_{4} \rightarrow \mathrm{P}_{4} \mathrm{O}_{10}+6 \mathrm{H}_{2} \mathrm{O}
$$

This is an example of an entropy-driven reaction where four molecules are converted to seven, so $\mathrm{P}_{4} \mathrm{O}_{10}$ is stable at high temperature $\left(K_{1,000 K}=10^{\prime \prime}\right)$. However, orthophosphate becomes so stable at low temperatures $\left(\mathrm{K}_{300 \mathrm{~K}}\right.$ $=10^{-62}$ ) that phosphorus pentoxide is the most powerful drying agent known.

There are two aspects to this synthesis that need to be understood to put it into a prebiotic context. First, does it proceed in most magmas or only in some examples? And secondly, how extensive could this synthesis have been on the prebiotic Earth? Let us assume that the yield of polyphosphate from orthophosphate is $100 \%$. At the present time approximately $1 \mathrm{~km}^{3}$ of lava is emitted per year $\left(0.1 \% \mathrm{P}, \rho=3 \mathrm{gcm}^{-3}\right)$. So $10^{11} \mathrm{~mol}$ of phosphate as polyphosphate would be produced per year. If this was dissolved in the present ocean of $1.5 \times 10^{21} \mathrm{I}$, then an increase in the condensed phosphate bond concentration of $7 \times 10^{-11} \mathrm{M}$ per year would result. Assuming a half-life for hydrolysis of 1,000 years (the rate in the absence of divalent cations at $0^{\circ} \mathrm{C}$ [Van Wazer 1958]) gives a steady-state concentration of $7 \times 10^{-8} \mathrm{M}$. This concentration is far too low to cause polymerization reactions to occur. Lava emissions are assumed to have been higher on the primitive Earth, perhaps by an order of magnitude, but this still would not affect our conclusions.

The above calculations are based on the best possible scenario. The yields for the volatilization of phosphorus pentoxide from lava are not known. The half-life for hydrolysis of polyphosphates used were those measured in aqueous solution in the absence of divalent cations. These are known to catalyze the hydrolysis of polyphosphates and are present in relatively high concentrations in all natural waters. A more realistic yield of $1 \%$ and half-life of 10 years would reduce the steady-state concentration of phosphate as condensed phosphate to around $10^{-11} \mathrm{M}$. If polyphosphates were utilized close to their source, before they were dispersed throughout the ocean, then volcanic sources may have been sufficient. This, however, greatly reduces the area within which polyphosphates would have occurred and introduces the problem of the transport of organic molecules into these environments.

\section{Can Polyphosphates Be Produced by Heating Rocks?}

Although apatite is the predominant phosphate mineral on the Earth today, it has been claimed that apatite is a biologically produced mineral and that whitlockite is the kinetic and thermodynamically favored product under sterile conditions and therefore was the major phosphate mineral on the primitive Earth (Arrhenius et al. 1993).

Whitlockite contains monohydrogen phosphate (Mazghouni et al. 1981) and when heated produces $-10 \%$ pyrophosphate and smaller amounts of higher condensed phosphates (Sales et al. 1992). This heating to $250-550^{\circ} \mathrm{C}$ took place in an open container so that the water could escape. We write the equation as

$$
2 n \mathrm{HPO}_{4}^{2-} \rightleftarrows\left(\mathrm{PO}_{3}\right) n+n \mathrm{H}_{2} \mathrm{O}+n \mathrm{PO}_{4}^{3-}
$$

Hence the reaction is driven to the right by the escape of water. In the geological environment, such open systems can occur on beaches, lagoon margins, fumaroles, etc. However, the water cannot escape from buried and heated rocks. It has been pointed out by Byrappa (1983) that this is the reason that pyrophosphate and polyphosphate minerals do not occur in Nature: the trapped water in the rock would drive the reaction below to the left:

$$
2 \mathrm{CaHPO}_{4} \rightleftarrows \mathrm{Ca}_{2} \mathrm{P}_{2} \mathrm{O}_{7}+\mathrm{H}_{2} \mathrm{O}
$$

This was experimentally investigated in the case of neodymium orthophosphates. Polyphosphates will not form in such systems if the equilibrium partial pressure of water is above about 6 atm. This can be generated hydrostatically, lithostatically, or by heating $10500^{\circ} \mathrm{C}$ at constant volume. The value for calcium phosphate would not be much different from that observed for neodymium phosphate.

There is an additional factor not generally recognized. Polyphosphate solids, particularly calcium and magnesium salts, frequently hydrolyze on attempts to dissolve 
Table 1. Some examples of the synthesis of phosphoanhydrides and phosphate esters using heat

\begin{tabular}{|c|c|c|c|c|}
\hline Starting phosphate & Heating conditions & Produce & Yield & Reference \\
\hline $\mathrm{NaH}_{2} \mathrm{PO}_{4}$ & $500-600^{\circ} \mathrm{C}$ & Cyclic trimetaphosphate & $100 \%$ & Van Wazer 1958 \\
\hline $\mathrm{NaH}_{2} \mathrm{PO}_{4}$ and $\mathrm{KH}_{2} \mathrm{PO}_{4}$ & $200-600^{\circ} \mathrm{C}$ & Linear polyphosphates & $100 \%$ & Van Wazer 1958 \\
\hline $\mathrm{NaH}_{2} \mathrm{PO}_{4}$ and uridine & $160^{\circ} \mathrm{C}$ & UMP & $16 \%$ & Ponnamperuma and Mack 1965 \\
\hline $\mathrm{Ca}\left(\mathrm{HPO}_{4}\right)_{2}$ and uridine & $160^{\circ} \mathrm{C}$ & UMP & $11 \%$ & Ponnamperuma and Mack 1965 \\
\hline $\mathrm{Na}_{2} \mathrm{HPO}_{4}$ and uridine & $160^{\circ} \mathrm{C}$ & UMP & $0.6 \%$ & Pannamperuma and Mack 1965 \\
\hline $\mathrm{NaH}_{2} \mathrm{PO}_{4}$ & $160^{\circ} \mathrm{C}$ & Pyrophosphate & $5-10 \%$ & Rabinowitz et al. 1968 \\
\hline $\mathrm{NaH}_{2} \mathrm{PO}_{4}$ & $160^{\circ} \mathrm{C}$ & Tripolyphosphate & $1-5 \%$ & Rabinowitz et al. 1968 \\
\hline $\mathrm{Na}_{2} \mathrm{HPO}_{4}$ & $160^{\circ} \mathrm{C}$ & Pyrophosphate & $5-10 \%$ & Rabinowitz et al. 1968 \\
\hline $\mathrm{Na}_{2} \mathrm{HPO}_{4}$ & $160^{\circ} \mathrm{C}$ & Tripolyphosphate & $1-5 \%$ & Rabinowitz et al. 1968 \\
\hline $\mathrm{CaHPO}_{4}$ & $160^{\circ} \mathrm{C}$ & Pyrophosphate & $30-50 \%$ & Rabinowitz et al. 1968 \\
\hline $\mathrm{CaHPO}_{4}$ & $160^{\circ} \mathrm{C}$ & Tripolyphosphate & $10-30 \%$ & Rabinowitz ef al. 1968 \\
\hline $\mathrm{NH}_{4} \mathrm{H}_{2} \mathrm{PO}_{4}$ and urea & $85-100^{\circ} \mathrm{C}$ & Linear polyphosphates & $60-100 \%$ & Österberg and Orgel 1972 \\
\hline $\begin{array}{l}\mathrm{Ca}_{3}\left(\mathrm{PO}_{4}\right)_{2} \text {, urea } \\
\text { and uridine }\end{array}$ & $85^{\circ} \mathrm{C}$ & UMP & $30-80 \%$ & Handschuh et al. 1973 \\
\hline $\begin{array}{l}\mathrm{Na}_{2} \mathrm{HPO}_{4} \text {, urea } \\
\text { and thymidine }\end{array}$ & $65^{\circ} \mathrm{C}$ & TMP & $25 \%$ & Bishop ef al. 1972 \\
\hline $\begin{array}{l}\mathrm{Ca}_{3}\left(\mathrm{PO}_{4}\right)_{2}, \\
\left(\mathrm{NH}_{4}\right)_{2} \mathrm{C}_{2} \mathrm{O}_{4} \text {, and thymidine }\end{array}$ & $90^{\circ} \mathrm{C}$ & TMP & $15-30 \%$ & Schwarz ef al. 1975 \\
\hline $\begin{array}{l}\mathrm{Ca}_{3}\left(\mathrm{PO}_{4}\right)_{2} \\
\left(\mathrm{NH}_{4}\right)_{2} \mathrm{C}_{2} \mathrm{O}_{4} \text {. and thymidine }\end{array}$ & $90^{\circ} \mathrm{C}$ & Polyphosphates & $1-50 \%$ & Schwartz et al. 1975 \\
\hline Trehalose & $56^{\circ} \mathrm{C}$ & Trehalose phosphate & $15 \%$ & Tarelli and Wheeler 1993 \\
\hline $\mathrm{MgHPO}_{+}$ & $250-550^{\circ} \mathrm{C}$ & Polyphosphates 2-10 mers & $50 \%$ & Sales et al. 1992 \\
\hline
\end{tabular}

them because of the strong crystal forces (Sales et al. 1993). This can be avoided in the laboratory by the use of chelating agents such as EDTA or oxalate that would not have been widely available on the primitive Earth.

If we assume that somehow this reverse reaction could be inhibited or if the water were somehow to escape or be removed, then a calculation similar to that for volcanic sources can be done. Approximately $1 \mathrm{~km}^{3}$ of sediment is weathered every year $\left(0.1 \% \mathrm{P}, \rho=3 \mathrm{gcm}^{-3}\right)$. Assuming that all of the phosphorus in this is converted to polyphosphates, then the steady-state concentration of condensed phosphate bonds would have been the same as before, $7 \times 10^{-8} \mathrm{M}$. Even if we add this steady-state concentration to that which was volcanically produced, then the result, $1.4 \times 10^{-7} \mathrm{M}$, is also far too low to cause polymerization reactions to occur.

We are therefore skeptical that heated rocks were a source at all of polyphosphates because (1) the widespread occurrence of whitlockite is doubtful, (2) heating in a closed system does not give polyphosphates, and (3) an efficient mechanism is not available to concentrate them in a local area.

\section{Thermal Syntheses of Polyphosphates}

The synthesis of metaphosphates by heating dihydrogen phosphates (and pyrophosphates by heating monohydrogen phosphates) has long been known (Berzelius 1816; Van Wazer 1958). The temperatures used were generally $200-600^{\circ} \mathrm{C}$. These were in open systems so that the water produced could escape. There are two problems in applying this to the prebiotic environment. The first is that dihydrogen phosphate minerals are not known in Nature today. The second problem is how to heat dihydrogen phosphate minerals at $200-600^{\circ} \mathrm{C}$ in open systems. This could have occurred if the whole surface of the Earth was at this temperature, but that would have destroyed all of the organic compounds. Local areas at $200-600^{\circ} \mathrm{C}$ would have been extremely limited in extent.

There have been many attempts to produce polyphosphates at lower temperatures with very limited success (Table 1). One exception is the synthesis of ammonium metaphosphate from ammonium dihydrogen phosphate at the more reasonable temperatures of $60-100^{\circ} \mathrm{C}$ (Lohrmann and Orgel 1971; Österberg and Orgel 1972; Österberg et al. 1973; Handschuh et al. 1973). This gets around the high-temperature problem, but we are still left with the problem of a prebiotic source of the ammonium dihydrogen phosphate.

$$
n \mathrm{NH}_{4} \mathrm{H}_{2} \mathrm{PO}_{4} \underset{\text { Excess urea }}{\stackrel{60-100^{\circ} \mathrm{C}}{\longrightarrow}} n \mathrm{NH}_{4} \mathrm{PO}_{3}+n \mathrm{H}_{2} \mathrm{O}
$$

It is not clear how solid ammonium dihydrogen phosphate could have accumulated. It is very soluble but excess calcium ions would preferentially precipitate $\mathrm{CaHPO}_{4}$ or $\mathrm{Ca}\left(\mathrm{H}_{2} \mathrm{PO}_{4}\right)_{2}$ on a drying beach or lagoon margin. Large amounts of urea could have occurred, but only after concentration by evaporation. There is also the problem of dispersing the polyphosphates into the whole ocean. However, this may be circumvented if the ammonium metaphosphate was produced and used before being washed into the ocean. 


\section{Can Polyphosphates be Concentrated?}

The polyphosphate problem could be overcome if the small amounts produced by volcanoes or other sources could have been concentrated in the critical area. The most obvious way of doing this is by the evaporation of a dilute solution of polyphosphates. This might work except that calcium ions are almost always more abundant than phosphate ions, and so the concentration is limited by the solubility of calcium polyphosphates ( 98 $\mu \mathrm{M}$ for calcium pyrophosphate, for example, Van Wazer, 1964). A chelating agent for calcium ions such as oxalate could have overcome this problem (Schwartz et al. 1975), but this would require oxalate to have been more abundant than the calcium ions, which is unlikely. Tripolyphosphates are used in laundry detergent formulations to solubilize calcium ions by chelating them, which only works when the tripolyphosphate is in excess concentration over the calcium ions. The same considerations apply to concentration by freezing.

Concentration of polyphosphates might have taken place close to a volcano or fumarole emitting phosphorus pentoxide, as was observed near Mt. Usu in Japan (Yamagata et al. 1991). Polyphosphate concentrations in these fumarole condensates were approximately micromolar. In addition, the resultant pools of water would have had a transient existence; the polyphosphates would hydrolyze, and a mechanism is needed to transport the organic compounds to be phosphorylated to these pools. Thus the areas where such concentration of polyphosphates could have taken place are so limited that they are of doubtful applicability.

Another possible process is to precipitate the polyphosphates and then solubilize them by removing the calcium or other metal ions. As discussed above, it is not likely that a calcium ion chelator would have been more abundant than the calcium ions. A related process is to somehow produce a massive deposit of calcium polyphosphates that either forms the bed of the lake or is a cliff at its side. This might work if the weathering was rapid enough, the concentration of calcium ions was low enough, and organic compounds were somehow supplied to the lake. This is highly improbable, owing to the multiplication of unlikely events (Shapiro 1986). This becomes even less likely if the continents had not yet formed.

A process related to precipitation is that of absorption onto a surface (e.g., of hydroxy apatite) or into a layered mineral (e.g., hydrotalcite). This would result in the concentration of the polyphosphates, and if organic compounds were also selectively absorbed, then there is the possibility of prebiotic phosphorylations taking place. There are a number of problems with this, such as whether the absorptions can take place from extremely dilute solutions (especially in the presence of chloride, carbonate, and other anions), the very limited area available, and how an adequate supply of dilute polyphosphate so- lution can pass through the mineral. For example. the interlayer region of hydrotalcite is $-10 \mathrm{M}$ in phosphate at saturation, so the concentration of polyphosphates to this level from a $10^{-10} \mathrm{~m}$ solution would require $10^{11}$ units of solution per unit of hydrotalcite. This is a large amount of water to be extracted $\left(100 \mathrm{~km}^{3}\right.$ of water per $\mathrm{m}^{3}$ of hydrotalcite). If this were to come from rain percolating through a thermally metamorphosed phosphorite, assuming $1 \mathrm{~m}$ per year. it would take $10^{11}$ years of rainfall to saturate a layer of hydrotalcite $1 \mathrm{~m}$ thick, or $10^{5}$ years for a layer $1 \mu \mathrm{m}$ thick.

\section{Chemical Polymerizations of Phosphate}

There have been a large number of attempts to polymerize phosphates using organic compounds with high free energies of hydrolysis. Examples include cyanate, cyanogen, cyanoacetylene, cyanamide, and hydrogen cyanide. None of these syntheses can be considered robust.

Some of these high-energy compounds have also been used to polymerize amino acids, but we will not discuss these here, nor will we discuss polymerizations using polyphosphates. We will first discuss the synthesis of polyphosphates and ADP from high-energy organic compounds and then take up the use of such compounds to synthesize organic phosphates.

The number of prebiotic syntheses of pyrophosphate and polyphosphates from high-energy organic compounds is limited and a representative sample is shown in Table 2 . The active reagent in the cyanate reactions is probably carbamyl phosphate which is formed reversibly from cyanate.

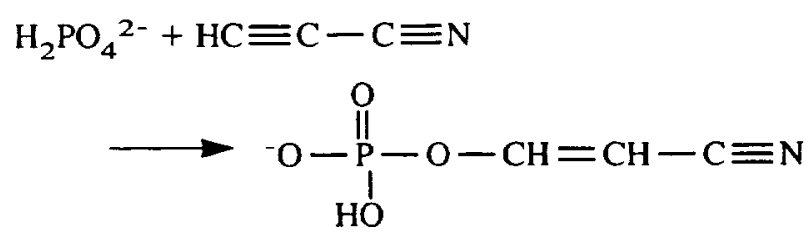

Cyanate and carbamyl phosphate have been produced in electric discharges (Yamagata and Mohri 1982) and from $\mathrm{Fe}(\mathrm{CN})_{6}{ }^{3-}$ by ultraviolet light (Saygin 1981). Carbamyl phosphate will phosphorylate AMP and ADP nonenzymatically as well as produce acetyl phosphate (Saygin 1983). A number of reagents failed to produce pyrophosphate or polyphosphates. These include carbodiimides, dicyandiamide, and cyanogen (Beck and Orgel 1965), succinic anhydride, maleic anhydride, and carbon suboxide (Keefe and Miller 1996).

The prebiotic phosphorylations of organic compounds are more extensive. Many of these are listed in Table 3. The data in the table show that there are a variety of phosphorylations possible, but most of them are relatively low-yield reactions and use high concentrations of reagents. Another characteristic of the efficient reactions 
Table 2. Some examples of the synthesis of phosphoanhydrides using high-energy organic compounds

\begin{tabular}{|c|c|c|c|c|}
\hline Organic reagent & Phosphate & Product & Yield & Reference \\
\hline Cyanate & Apatite & Pyrophosphate & $26 \%$ & Miller and Parris 1964 \\
\hline Cyanate & Apatite & Pyrophosphate & $1-2 \%$ & Beck and Orgel 1965 \\
\hline $\begin{array}{l}\text { Cyanate and } \\
\text { calcium phosphate }\end{array}$ & Tripolyphosphate & Trimetaphosphate & $1 \%$ & Beck and Orgel 1965 \\
\hline $\begin{array}{l}\text { Cyanate } \\
\text { (Electric discharge) }\end{array}$ & Phosphate & Carbamyl phosphate & $6 \%$ & Yamagata and Mohri 1982 \\
\hline $\begin{array}{l}\text { Cyanate } \\
\text { (Electric discharge) }\end{array}$ & Adenosine & AMP & $2 \%$ & Yamagata et al. 1979. 1981 \\
\hline Carbamyl phosphate & AMP, ADP & ADP, ATP & $2-17 \%$ & Saygin 1981 \\
\hline Carbamyl phosphate & Acetate & Acetyl phosphate & $30 \%$ & Saygin 1983 \\
\hline $\begin{array}{l}\text { Ferricyanide and } \\
\text { visible light }\end{array}$ & Phosphate & Carbamyl phosphate & $15 \%$ & Saygin 1981 \\
\hline Cyanamide & Phosphate & Pyrophosphate & $?$ & Steinman et al. 1964 \\
\hline Dicyandiamide & Phosphate & Pyrophosphate & $0.2-1.8 \%$ & Steinman et al. 1965 \\
\hline Dicyandiamide & ADP & ATP & $\begin{array}{l}<0.03 \% \\
0.5 \% \text { (Kaolin) }\end{array}$ & Steinman et al. 1965 \\
\hline Dicyandiamide & Phosphate & Pyrophosphate & $<0.1 \%$ & Beck and Orgel 1965 \\
\hline Carbodiimide & Phosphate & Pyrophosphate & $<0.1 \%$ & Beck and Orgel 1965 \\
\hline Thioesters & Phosphate & Pyrophosphate & $2-11 \%$ & Weber 1982 \\
\hline $\begin{array}{l}\text { Diacetyl cysteamine } \\
\text { and imidazole }\end{array}$ & Phosphate & $\begin{array}{l}\text { Pyrophosphate and } \\
\text { tripolyphosphate }\end{array}$ & $3-8 \%$ & Weber 1981 \\
\hline Dithionite and oxygen & Phosphate & Pyrophosphate & $0.24 \%$ & Gabel 1968 \\
\hline Cyanamide & dTMP & dTppdT & $58 \%$ & Sherwood and Oró 1977 \\
\hline Ammonium formate & Phosphate & Pyrophosphate & $53 \%$ & Keefe and Miller 1996 \\
\hline $\begin{array}{l}\text { Thiocyanate and } \\
\text { hydrogen peroxide }\end{array}$ & Phosphate & Pyrophosphate & $26 \%$ & Keefe and Miller 1996 \\
\hline Maleic anhydride & Phosphate & Pyrophosphate & $5 \%$ & Keefe and Miller 1996 \\
\hline Pantoyl lactone & Phosphate & Pyrophosphate & $5 \%$ & Keefe and Miller 1996 \\
\hline Polymerizing $\mathrm{HCN}$ & Phosphate & Pyrophosphate & $4 \%$ & Keefe and Miller 1996 \\
\hline $\begin{array}{l}\text { Imidazole and } \\
\text { calcium chloride }\end{array}$ & Phosphate & Pyrophosphate & $4 \%$ & Keefe and Miller 1996 \\
\hline
\end{tabular}

is that while the organic compound is very efficient in reaction with phosphate, the product is a poor or nonselective phosphorylating agent. The best example is cyanoacetylene (Ferris et al. 1970)

$$
\begin{aligned}
\mathrm{H}_{2} \mathrm{PO}_{4}{ }^{2-}+\mathrm{HC} \equiv \mathrm{C}-\mathrm{C} \equiv \mathrm{N} \\
\longrightarrow-\mathrm{O}-\prod_{\mathrm{PO}}^{\mathrm{O}}-\mathrm{O}-\mathrm{CH}=\mathrm{CH}-\mathrm{C} \equiv \mathrm{N}
\end{aligned}
$$

which reacts with phosphate at concentrations as low as $10^{-6} \mathrm{M}$, probably via a cyclic transition state, but the cyanovinyl phosphate is a poor phosphorylating agent.

There is one consideration that has not previously been taken into account: Even the most efficient highenergy carbon compounds cannot generate large amounts of polyphosphates. Let us assume that we start with 1 atm pressure of methane or carbon monoxide and assume that hydrogen cyanide is made quantitatively from the carbon source. This will give $36 \mathrm{~mol} \mathrm{~cm}^{-2}$ of hydrogen cyanide. If this is dissolved in an ocean of the present size and each hydrogen cyanide molecule gives rise to one condensed phosphate bond via the formation of a high-energy organic compound, then the concentra- tion of condensed phosphate bonds would be $0.12 \mathrm{M}$. However, this production of hydrogen cyanide would take some time. Assuming that the hydrogen cyanide was produced over a period of one million years and that the half-life of the hydrolysis of pyrophosphate bonds is 1,000 years, the steady-state concentration of pyrophosphate bonds would be $1.2 \times 10^{-4} \mathrm{M}$. It would be surprising if even $1 \%$ of this value were achievable. Keeping in mind that this is a very favorable case and hydrogen cyanide has not been shown to make polyphosphate bonds at all, the use of high-energy carbon compounds produced from atmospheric constituents does not seem promising. There are possible ways around this. The atmospheric carbon might be recirculated, the time periods of 1,000,000 and 1,000 years might be adjusted, and the high-energy compounds might be concentrated in a local area.

\section{The Beilstein Experiment-An Attempt to Find a Prebiotic Compound Which can Condense Orthophosphate Efficiently}

As discussed above, none of the high-energy compounds used to produce polyphosphates have proved particularly efficient. If some high-energy organic compound capable of polymerizing phosphate has been overlooked, it 
Table 3. Some examples of the synthesis of phosphate esters using high energy organic compounds

\begin{tabular}{|c|c|c|c|c|}
\hline High energy compound & Reactant & Product & Yield & Reference \\
\hline Cyanate (electric discharge) & Adenosine & AMP & $0.02 \%$ & Yamagata ef al. 1979,1981 \\
\hline Cyanate & Uridine & UMP & $1 \%$ & Lohrmann and Orgel 1968 \\
\hline Cyanamide (pH 2) & Glucose & Glucose-6-phosphate & $1.5 \%$ & Steinman et al. 1964 \\
\hline Cyanamide & Ribose & Ribose-1-phosphate & $8 \%$ & Halmann et al. 1969: Halmann and Scmidt 1970 \\
\hline Carbodiimide & Uridine & UMP & $3 \%$ & Lohrmann and Orgel 1968 \\
\hline Dicyandiamide ( $\mathrm{pH} 2)$ & Glucose & Glucose-6-phosphate & $2.4 \%$ & Steinman et al. 1964 \\
\hline Dicyandiamide ( $\mathrm{pH} \mathrm{2)}$ & Adenosine & AMP & $?$ & Steinman et al. 1964 \\
\hline Dicyandiamide & Glucose & Glucose-6-phosphate & $1.9 \%$ & Steinman et al. 1965 \\
\hline Cyanogen & Ribose & Ribose-1-phosphate & $20 \%$ & Halmann et al. 1969; Halmann and Schmidt 1970 \\
\hline Cyanogen & Deoxyribose & Deoxyribose-1-phosphate & $0 \%$ & Halmann et al. 1969; Halmann and Schmidt 1970 \\
\hline $\mathrm{NCCONH}_{2}$ & Uridine & UMP & $2 \%$ & Lohrmann and Orgel 1968 \\
\hline Ethylisocyanide & Uridine & UMP & $1-10 \%$ & Lohrmann and Orgel 1968 \\
\hline Oxiranecarbonitrile & Phosphate & Glycoaldehyde phosphate & $47 \%$ & Pitsch ef al. 1994 \\
\hline $\begin{array}{l}\text { Diiminosuccinonitrile } \\
\text { or cyanogen bromide }\end{array}$ & AMP & CAMP & $18 \%$ & Ferris et al. 1984 \\
\hline Diiminosuccinonitrile & Uridine & UMP & $4 \%$ & Ferris et al. 1984 \\
\hline Cyanogen bromide & AMP 6-mer & AMP polymer & $68 \%$ & Kanaya and Yanagawa 1986 \\
\hline$N$-cyanoimidazole & DNA 12-mer & DNA 24-mer & $75 \%$ & $\mathrm{Li}$ and Nicolaou 1994 \\
\hline Carbodiimide & DNA 6-mer & DNA 12-mer & ? & Sievers and von Kiedrowski 1994 \\
\hline Cyanamide & dTTP & dTMP oligomers & $80 \%$ & Sherwood et al. 1977 \\
\hline
\end{tabular}

should prove possible to detect such a compound by conducting a "Beilstein" (Prager and Jacobson 19181940) experiment. This is where almost all possible prebiotic organic compounds are synthesized simultaneously in an electric discharge (or other energy source) and allowed to react with an aqueous solution of orthophosphate. A 3-I flask with tungsten electrodes contained $100 \mathrm{ml}$ of aqueous solution, $1 \mathrm{~mm}$ in sodium orthophosphate or tripolyphosphate and optionally $0.5 \mathrm{~mm}$ in $\mathrm{CaCl}_{2}$ and $0.5 \mathrm{mM} \mathrm{MgCl}$. The $\mathrm{pH}$ was adjusted to 8.2 . The indicated gases were each 200 torr. The electric discharge was induced by a high-frequency $1-W$ Tesla coil. After $48 \mathrm{~h}$ the resulting solution was concentrated by evaporation to approximately $0.5 \mathrm{~cm}^{3}$, EDTA was added, and the yields of phosphorus products were determined by ${ }^{3 !} \mathrm{P}$ nuclear magnetic resonance (NMR) at 121.5 MHz on a General Electric QE300 NMR spectrometer using phosphoric acid as an external reference.

The results of the discharge experiments are given in Table 4 . The products were undetectable $(<1 \%)$ using orthophosphate with or without calcium and magnesium ions. This experiment is more representative of a primitive Earth process than the usual experiments with highenergy compounds such as cyanate or cyanoacetylene in that the conditions are not so selective. Even so, we have used concentrations of orthophosphate far higher than are reasonable and still the yields were undetectable.

Because orthophosphate did not produce any product, we considered the possibility that a minor phosphate species could act as a high-energy phosphate by repeated recycling. For example, tripolyphosphate can be cyclized to trimetaphosphate, which is a phosphorylating agent, regenerating the tripolyphosphate as a product. Therefore, only a relatively small amount of tripolyphosphate would have to be synthesized by another route in the first place. Table 4 also shows the yields with tripolyphosphate. Hexapolyphosphate was detected rather than cyclic trimetaphosphate because the trimetaphosphate produced apparently reacts with tripolyphosphate. The $20 \%$ yield of hexapolyphosphate $\left(\mathrm{P}_{6} \mathrm{O}_{19}{ }^{8-}\right)$ with $\mathrm{CO} / \mathrm{N}_{2}$ is substantial, but it is not clear how efficient this reaction would have been on the prebiotic Earth. The yield becomes undetectable $(<1 \%)$ on the addition of calcium and magnesium ions. The tripolyphosphate concentration in the experiment was much higher than it is reasonable to expect for the prebiotic Earth.<smiles></smiles>

\section{Conclusion}

These results are in accord with a long line of prebiotic experiments. Pyrophosphate and polyphosphates can be synthesized under conditions considered to be prebiotic, but the yields are generally low and the conditions are rather forced. In particular the use of high concentrations of soluble orthophosphate $\left(>10^{-3} \mathrm{M}\right)$ cannot be considered prebiotic. The solubility of orthophosphate in the 
Table 4. Percent yields of new condensed phosphates from electric discharges in various prebiotic atmospheres:

\begin{tabular}{|c|c|c|c|c|}
\hline \multirow[b]{2}{*}{ Atmosphere } & \multicolumn{2}{|c|}{$\begin{array}{l}\text { Percent yield of } \\
\text { pyrophosphite } \\
\text { from } \\
\text { orthophosphate }\end{array}$} & \multicolumn{2}{|c|}{$\begin{array}{l}\text { Percent yield of } \\
\text { hexapolyphosphate } \\
\text { from } \\
\text { tripolyphosphate }\end{array}$} \\
\hline & $\mathrm{Na}^{+}$ & $\begin{array}{l}\mathrm{Na}^{+} \\
\mathrm{Ca}^{2+} \\
\mathrm{Mg}^{2+}\end{array}$ & $\mathrm{Na}^{+}$ & $\begin{array}{l}\mathrm{Na}^{+} \\
\mathrm{Ca}^{2+} \\
\mathrm{Mg}^{2+}\end{array}$ \\
\hline $\mathrm{CH}_{4} / \mathrm{H}_{2} \mathrm{~S} / \mathrm{N}_{2}$ & 0 & 0 & 12 & 0 \\
\hline $\mathrm{CH}_{4} / \mathrm{NH}_{3}$ & 0 & 0 & 8 & 4 \\
\hline $\mathrm{CH}_{4} / \mathrm{N}_{2}$ & 0 & 0 & 6 & 0 \\
\hline $\mathrm{CO}$ & 0 & 0 & 0 & 0 \\
\hline $\mathrm{CO} / \mathrm{H}_{2}$ & 0 & 0 & 0 & 0 \\
\hline $\mathrm{CO} / \mathrm{N}_{2}$ & 0 & 0 & 20 & 0 \\
\hline $\mathrm{CO}_{2} / \mathrm{N}_{2} / \mathrm{H}_{2}$ & 0 & 0 & 0 & 0 \\
\hline $\mathrm{CO}_{2} / \mathrm{N}_{2}$ & 0 & 0 & 0 & 0 \\
\hline
\end{tabular}

"The 3-1 flask with tungsten electrodes contained $100 \mathrm{ml}$ of aqueous solution, $1 \mathrm{~mm}$ in sodium orthophosphate or tripolyphosphate, and optionally $0.5 \mathrm{~mm}$ in $\mathrm{CaCl}_{2}$ and $0.5 \mathrm{mM} \mathrm{MgCl}$. The $\mathrm{pH}$ was adjusted 10 8.2. The indicated gases were each 200 torr. The electric discharge was induced by a high-frequency I-W Tesla coil. After $48 \mathrm{~h}$ the resulting solution was concentrated by evaporation to approximately 0.5 $\mathrm{cm}^{3}$, EDTA was added, and the yields of phosphorus products were determined by ${ }^{31} \mathrm{P}$ NMR at $121.5 \mathrm{MHz}$ on a General Electric QE300 NMR spectrometer using phosphoric acid as an external reference. Orthophosphate (singlet 5 to $-1 \mathrm{ppm}$ ) is easily distinguished from pyrophosphate (singlet -6 to $-12 \mathrm{ppm}$ ), the terminal phosphorus of tripolyphosphate (singlet -6 to $-12 \mathrm{ppm}$ ), the central phosphorus of tripolyphosphate (triplet -18 to $-22 \mathrm{ppm}$ ), trimetaphosphate (singlet -18 to $-22 \mathrm{ppm}$ ), and hexapolyphosphate (multiplet -18 to $-22 \mathrm{ppm}$ ) Hexapolyphosphate was detected rather than cyclic trimetaphosphate because the trimetaphosphate produced apparently reacts with tripolyphosphate

present ocean is $3 \times 10^{-6} \mathrm{M}$, and as far as we are aware a natural water containing even $10^{-3} \mathrm{M}$ orthophosphate has never been reported. The concentration of orthophosphate in the prebiotic ocean may have been higher if the $\mathrm{pH}$ was lower. But even this would not result in high concentrations of dissolved orthophosphate at reasonable $\mathrm{pH}$ values, and the hydrolysis of condensed phosphates under acidic conditions is much more rapid. Phosphorus is not an especially abundant element with crustal rocks containing on average only $0.09 \%$ (Vinogradov 1965). If all the phosphorus presently in the top $1 \mathrm{~km}$ of the crust was dissolved in the modern ocean the concentration would still only be $3 \times 10^{-2} \mathrm{M}$.

One way around the problem would be to utilize the orthophosphate on the surface of apatite or other orthophosphate minerals. This so far has not proved to be particularly successful, although some positive results have been obtained (Miller and Parris 1964; Beck and Orgel 1965). Some phosphate mineral surfaces hydrolyze phosphate anhydrides such as ATP (Krane and Glimcher 1962). The addition of calcium and magnesium to our experiments quenched the pyrophosphate and hexapolyphosphate syntheses with few exceptions.
These results suggest that it may not be possible to produce adequate concentrations of high-energy phosphates using electric discharges or volcanic sources. We recognize that we may have missed some high energy compounds in these experiments so this statement needs to be taken with some reservation.'

An alternative to the high local phosphate concentration hypothesis is to assume that phosphates did not play a part in the formation of the first living organism, either as a structural component of the pre-RNA molecules or as a free energy source. An example of an informational molecule with a nonphosphate backbone is the peptide nucleic acid system of Egholm et al. (1992). This mimics the structure of DNA quite well and indeed binds to DNA better than DNA does to itself. It is possible that the backbone for the first genetic material was not a polymer with a repeating unit. Thus the bases could have been held in place by a cyanide polymer or an acrolein amino acid polymer (Nelsestuen 1980). In addition there are models of the origin of life that do not involve phosphate, such as the clay theory of Cairns-Smith (1982) and the thioester world of de Duve (1991).

It may be more difficult to account for an alternative free energy source. The usual reagents, as discussed above, used to polymerize peptides or produce polyphosphates could be proposed, but their applicability would need to be investigated for the particular proposed protometabolic pathway or alternative genetic material. Another possibility is that the polymer has a negative free energy of formation from its precursors and therefore forms spontaneously. An example of this is the formation of polyglycine from glycine nitrile: this is thermodynamically favorable even at low concentrations, although it does not actually occur unless the glycine nitrile is very concentrated (Hanafusa and Akabori 1959; Losse and Anders 1961; Moser and Matthews 1968).

There may still be an undiscovered robust prebiotic synthesis of polyphosphates, or a mechanism of concentrating them, and we do not want to discourage further work in this area. In addition, it cannot be excluded that there are prebiotic processes requiring only small amounts of polyphosphates to take off and form selfreplicating systems. However, we believe that alternative prebiotic free energy sources to polyphosphates deserve serious consideration and that searches in this area may be more fruitful than further attempts to find a prebiotic source of polyphosphates.

Acknowledgments. We thank the NASA Specialized Center of Research and Training (NSCORT) in exobiology at the University of

\footnotetext{
'It is perhaps significant that there have been few experiments in the last 20 years attempting to produce high-energy phosphates. This suggests that robust syntheses may not be possible.
} 
California San Diego for a postdoctoral fellowship (A.D.K.) and grant support (S.L.M.).

\section{References}

Arrhenius G, Gedulin B. Mojzsis S (1993) Phosphate in models for chenical evolution. In: Ponnamperuma C. Chela-Flores $\mathrm{J}$ (eds) Conference on chemical evolution and the origin of life. proceed ings. Trieste. 1992. A. Deepak Publishing, Hampton, VA. pp 25-50

Baltscheffsky $H$ (1993) Chemical origin and early evolution of biological energy conversion. In: Ponnamperuma C. Chela-Flores J (eds) Conference on chemical evolution and the origin of life, proceedings. Trieste. 1992. A. Deepak Publishing, Hampton. VA, pp 13-23

Beck A. Orgel LE (1965) The formation of condensed phosphate in aqueous solution. Proc Natl Acad Sci USA 54:664-667

Berzelius. JJ (1816) Untersuchungen über die Zusammensetzung der Phosphorsäure. der phosphorigen Säure und ihrer Salze. Ann Physik 53:393-446

Bishop. MJ, Lohrmann, R, Orgel, LE (1972) Prebiotic phosphorylation of thymidine at $65^{\circ} \mathrm{C}$ in simulated desert conditions. Nature 237: 162-164

Byrappa, K (1983) The possible reasons for the absence of condensed phosphates in Nature. Phys Chem Miner 10:94-95

Cairns-Smith, AG (1982) Genetic takeover and the mineral origins of life. Cambridge Unjversity Press, Cambridge, England

de Duve, C (1991) Blueprint for a cell: the nature and origin of life. N. Patterson Publishers, Burlington, NC

Egholm, M, Buchardt, O, Nielsen, PE, Berg, RH (1992) Peptide nucleic acids (PNA). Oligonucleotide analogues with an achiral peptide backbone. J Am Chem Soc 114:1895-1897

Ferris JP (1968) Cyanovinyl phosphate: a prebiological phosphorylating agent? Science 161:53-54

Ferris JP, Goldstein G, Beaulieu DJ (1970) Chemical evolution IV. An evaluation of cyanovinyl phosphate as a prebiotic phosphorylating agent. J Am Chem Soc 92:6598-6603

Ferris, JP, Yanagawa, H. Dudgeon, PA, Hagan Jr WJ, Mallare, TE (1984) The investigation of the HCN derivative diiminosuccinonitrile as a prebiotic condensing agent. The formation of phosphate esters. Orig Life 15:29-43

Gabel, NW (1968) Abiotic formation of phosphoric anhydride bonds in dilute aqueous conditions. Nature 218:354

Halmann, M, Sanchez, RA, Orgel LE (1969) Phosphorylation of D-ribose in aqueous solution. J Org Chem 34:3702-3703

Halmann, M. Schmidt, H-L (1970) Cyanogen-induced synthesis of ${ }^{18} \mathrm{O}$-labelled $\beta$-ribofuranose- 1 -phosphate and its acid-catalysed hydrolysis. J Chem Soc (C) 1970:1191-1193

Hanafusa, H, Akabori, S (1959) Polymerization of aminoacetonitrile. Bull Chem Soc Jpn 32:626-630

Handschuh, GJ, Orgel, LE (1973) Struvite and prebiotic phosphorylation. Science 179:483-484

Handschuh, GJ, Lohrmann, R, Orgel, LE (1973) The effect of $\mathrm{Mg}^{2+}$ and $\mathrm{Ca}^{2+}$ on urea-catalyzed phosphorylation reactions. J Mol Evol 2:251-262

Hulshof, J, Ponnamperuma. C (1976) Prebiotic condensation reactions in an aqueous medium: a review of condensing agents. Orig Life 7:197-224

Kanaya, E, Yanagawa, H (1986) Template-directed polymerization of oligoadenylates using cyanogen bromide. Biochemistry 25:74237430

Keefe AD. Miller SL (1996) Potentially prebiotic syntheses of condensed phosphates. Orig Life Evol. Biosphere (in press)

Kornberg, A (1995) Inorganic polyphosphate: toward making a forgotten polymer unforgettable. J Bacteriol 177:491-496

Krane, SM, Glimcher, MJ (1962) Transphosphorylation from nucleo- side di- and triphosphates by apatite crystals. J Biol Chem 237: 2991-2998

Li, T. Nicolaou, KC (1994) Chemical self-replication of palindromic duplex DNA. Nature 369:218-221

Lohrmann. R, Orgel. LE (1968) Prebiotic synthesis: phosphorylation in aqueous solution. Science 161:64-66

Lohrmann, R. Orgel, LE (1971) Urea-inorganic phosphate mixtures as prebiotic phosphorylating agents. Science 171:490-494

Lohrmann. R. Orgel. LE (1973) Prebiotic activation processes. Nature 244:418-420

Losse, G. Anders. K (1961) Die Polymerisation von $\alpha$-Aminopropionitril an mineralischen Trägern als Modell für die primäre Bildung von Eiweißstoffen auf der Erde. Z. Physiol Chem 323: $111-115$

Martens. CS, Harriss, RC (1970) Inhibition of apatite precipitation in the marine environment by magnesium ions. Geochim Cosmochim. Acta 34:621-625

Mazghouni. M. Kbir-Ariguib, N, Counioux, JJ, Sebaoun, A (1981) Etude des equilibres solide-liquide-vapeur des systemes binaires $\mathrm{K}_{3} \mathrm{PO}_{4}-\mathrm{H}_{2} \mathrm{O}$ et $\mathrm{Mg}_{3}\left(\mathrm{PO}_{4}\right)_{2}-\mathrm{H}_{2} \mathrm{O}$. Thermochim Acta 47:125-139

Miller, SL. Parris. M (1964) Synthesis of pyrophosphate under primitive Earth conditions. Nature 204:1248-1250

Miller SL. Orgel LE (1974) The origins of life on the earth. Prentice Hall, Englewood Cliffs, NJ

Moser. RE. Matthews, CN (1968) Hydrolysis of aminoacetonitrile: peptide formation. Experientia 24:658-659

Nelsestuen, GL (1980) Origin of life: consideration of alternatives to proteins and nucleic acids. J Mol Evol 15:59-72

Nriagu, JO, Moore, PB (1984) Phosphate minerals. Springer-Verlag. Berlin

Österberg, R, Orgel, LE (1972) Polyphosphate and trimetaphosphate formation under potentially prebiotic conditions. J Mol Evol 1:241248

Österberg, R, Orgel, LE, Lohrmann, R (1973) Further studies of ureacatalyzed phosphorylation reactions. J Mol Evol 2:231-234

Palache, C, Berman, H. Frondel, C (195I) Dana's system of mineralogy, 7th ed, vol 2. John Wiley and Sons, New York

Pitsch, S, Pombo-Villar, E, Eschenmoser, A (1994) Chemistry of $\alpha$-aminonitriles. Formation of 2-oxoethyl phosphates ("glycoaldehyde phosphates") from rac-oxiranecarbonitrile and on (formal) constitutional relationships between 2-oxoethyl phosphates and oligo (hexo- and pentopyranosyl) nucleotide backbones. Helv Chim Acta 77:2251-2285

Ponnamperuma, C, Mack, R (1965) Nucleotide synthesis under possible primitive Earth conditions. Science 148:1221-1223

Prager, B, Jacobson, P. (eds) (1918-1940) Beilsteins Handbuch der organischen Chemie. Springer-Verlag. Berlin

Rabinowitz, J, Chang, S, Ponnamperuma, C (1968) Phosphorylation on the primitive earth. Nature 218:442-443

Rouse RC, Peacor DR, Freed RL (1988) Pyrophosphate groups in the structure of canaphite, $\mathrm{CaNa}_{2} \mathrm{P}_{2} \mathrm{O}_{7} \cdot 4 \mathrm{H}_{2} \mathrm{O}$ : the first occurrence of a condensed phosphate as a mineral. Am Miner 73:168-171

Sales, BC, Chakoumakos, BC, Boatner. LA, Ramey JO (1992) Structural evolution of the amorphous solids produced by heating crystalline $\mathrm{MgHPO}_{4} \cdot 3 \mathrm{H}_{2} \mathrm{O}$. J Mater Res 7(10):2646-2649

Sales, BC, Chakoumakos, BC, Boatner, LA, Ramey JO (1993) Structural properties of the amorphous phases produced by heating crystalline $\mathrm{MgHPO}_{4} \cdot 3 \mathrm{H}_{2} \mathrm{O}$. J Non-crystall Solids 159:121-139

Saygin, Ö (1981) Nonenzymatic photophosphorylation with visible light. A possible mode of prebiotic ATP formation. Naturwissenschaften 68:617-619

Saygin, Ö (1983) Nonenzymatic phosphorylation of acetate by carbamyl phosphate. A model reaction for prebiotic activation of carboxyl groups. Orig Life 13:43-48

Schwartz. AW, Van der Veen, M, Bisseling, T, Chittenden. GJF (1975) Prebiotic nucleotide synthesis-demonstration of a geologically plausible pathway. Orig Life 6:163-168 
Sievers, D, von Kiedrowski, G (1994) Self-replication of complementary nucleotide-based oligomers. Nature 369:221-224

Shapiro, R (1986) Origins, a skeptic's guide to the creation of life on earth. Simon and Schuster. New York

Sherwood. E. Oró, J (1977) Cyanamide mediated syntheses under plausible primitive earth conditions $I$. The synthesis of $\mathrm{P}^{1}, \mathrm{P}^{2}$ dideoxythymidine 5'-pyrophosphate. J Mol Evol 10:183-192

Sherwood E. Joshi A. Oró J (1977) Cyanamide mediated syntheses under plausible primitive earth conditions II. The polymerization of deoxythymidine 5'-triphosphate. J Mol Evol 10:193-209

Steinman. G, Lemmon, RM, Calvin. M (1964) Cyanamide: a possible key compound in chemical evolution. Proc Natl Acad Sci USA $52: 27-30$

Steinman, G, Kenyon, DH. Calvin, M (1965) Dehydration condensation in aqueous solution. Nature 206:707-708

Tarelli. E. Wheeler. SF (1993) Formation of esters. especially phosphate esters, under 'dry' conditions and 'mild' pH. Chem Industry 1993:164-165

Van Wazer, JR (1958) Phosphorus and its compounds, vol I. Interscience, New York

Vinogradov, AP (1956) Regularity of distribution of chemical elements in the Earth's crust. Geochemistry $44: 1-43$
Weber, AL (1981) Formation of pyrophosphate, tripolyphosphate. and phosphorylimidazole with the thioester. N. S-diacetylcysteamine, as the condensing agent. J Mol Evol 18:24-29

Weber. AL (1982) Formation of pyrophosphate on hydroxyapatite with thioesters as condensing agents. Biosystems 15:183-189

Westheimer. FH (1987) Why Nature those phosphates. Science 235: 1173-1178

Wood, HG (1985) Inorganic pyrophosphate and polyphosphates as sources of energy. Curr Top Cell Regul 26:355-369

Yamagata, Y, Matsukawa. T. Mohri. T. Inomata, K (1979) Phosphorylation of adenosine in aqueous solution by electric discharges. Nature 282:284-286

Yamagata, Y, Mohri. T, Yamakoshi. M, Inomata, K (1981) Constant AMP synthesis in aqueous solution by electric discharges. Orig Life 11:233-235

Yamagata, Y, Mohri, T (1982) Formation of cyanate and carbamyl phosphate by electric discharges of model primitive gas. Orig Life $12: 41-44$

Yamagata, Y, Watanabe, H. Saitoh. M, Namba. T (1991) Volcanic production of polyphosphates and its relevance to prebiotic evolution. Nature 352:516-519 